\title{
PUBLIC DEBT IN NEW EU MEMBER STATES - PANEL DATA ANALYSIS AND MANAGERIAL IMPLICATIONS*
}

\author{
Mario Pečarič ${ }^{* *}$ \\ Vlado Sliškovic ${ }^{* * *}$ \\ Tino Kusanovic ${ }^{* * * *}$
}

Received: 23. 5. 2017

Original scientific paper

Accepted: 10. 5. 2018

UDC 336.27(4-67EU-773)

DOI https://doi.org/10.30924/mjcmi/2018.23.2.81

\begin{abstract}
The paper argues that it is impossible to resolve the public debt problem within the existing economic policy model without changing the conceptual relationship between monetary and fiscal policy, i.e. without reconfirming the relationship between the policies and without strengthening the fiscal policy role. Otherwise, it is believed, the current model leads to a recession, while public debt problem remains unresolved. The existing model does not question the creation and
\end{abstract}

\section{INTRODUCTION - PUBLIC DEBT AS A STRUCTURAL MONETARY AND FISCAL PHENOMENON}

The sovereign debt crisis has birthed a great theoretical debate regarding both its causes and consequences but also regarding the need for more fiscal limits and greater fiscal consolidation efforts based on EU/EMU mainstream model of economic policy. structure of private debt and its effects on public debt, but the attention is given only to irresponsible fiscal policy. Understanding the public debt determinants is a prerequisite for effective public debt management and for private agents' positive expectations. In the paper, several managerial implications of the research results are, also, identified and presented.

Keywords: public debt management, EU monetary and fiscal policy, determinants of public debt

Although the current debt problem is the problem of debt explosion in general, both public and private, stigmatization of public debt stems from the structural understanding of fiscal policy's role within the neoclassical mainstream model of "competitive deflation" among the EMU, as well as among the non-EMU countries. According to the given model, fiscal policy has to be neutral, while the common monetary policy ensures price stability and growth based on the idea of

\footnotetext{
* This work has been supported in part by the Croatian Science Foundation under the project number IP-2013-11- 8174.

** Mario Pečarić, PhD, Professor, University of Split, Faculty of Economics, Business and Tourism, Cvite Fiskovića 5, 21000 Split, Croatia, e-mail: mpecaric@efst.hr

${ }^{* * *}$ Vlado Slišković, University of Split, PhD student, Faculty of Economics, Business and Tourism, e-mail: vlado.sliskovic@gmail.com

${ }^{* * * *}$ Tino Kusanović, University of Split, University Department of Professional Studies, 
free movement of capital and financial integration which was intended to be achieved through "forced convergence" of the countries' economies.

This paper argues that it is impossible to resolve the public debt problem within the existing model without changing the conceptual relationship between monetary and fiscal policy, without reconfirming the relationship between the policies and without strengthening the fiscal policy role in the same time. Otherwise, it is believed, the current economic policy model leads to a recession, while the public debt problem remains unresolved.

The existing model does not question the creation and structure of private debt and its effects on public debt, but the attention is given to irresponsible fiscal policy. The private debt problem is, therefore, neglected due to conceptual limitations of the existing architecture. The alternative logic sees structure, sources and volatility of private debt as significant for economic growth and, thus, for the stability of public debt itself, expressed in relative terms to GDP. The current crisis and the emergence of debt are both results of volatility of capital inflows and inability of the existing monetary and fiscal set-up to provide adequate response to volatility in private debt levels, particularly private sector loans, in highly financialized economies.

The starting point of this research is the view that public debt is not only a fiscal problem but a monetary-financial phenomenon. Public debt drivers are, to a large extent, out of fiscal policy scope. Therefore, the problem of public debt is a structural financial problem.

Contrary to this approach, the European sovereign debt crisis is widely believed to have its origins in fundamental macroeconomic imbalances, therefore austerity policy is largely seen as necessary with the aim of regaining the financial markets' trust. Given that, the public debt crisis is understood as competitiveness crisis, expressed in high external debt, or current account deficit. We, however, believe this is a wrong diagnosis. It is increasingly being confirmed that in the situation where government and private sector are deleveraging, and where the current account deficit is being reduced, as is the case for the selected EU New Member States (NMS) which we analyse, the balance is being established at the lower employment capacity level.

This paper aims at addressing questions like: "In what particular degree are the macroeconomic imbalances the cause of the sovereign debt crisis?", "Is the public debt issue purely a reflection of inadequate policies (such as the excessive governmental expenditure) or is it caused by the overall institutional failure within the Union's design?

The authors accept heterodox, mainly the Post-Keynesian thesis focusing on the need to focus more on the volatility of capital flows. Moreover, the authors support the view that the austerity measures impact imports more than exports.

The paper explores macroeconomic determinants of public debt in post-transitional NMS. As such, the research aims at contributing to better understanding, thereby more efficient managing, of public debt though application of adequate economic policy. It is believed this can be achieved only by understanding its causes as well as its consequences, the latter meaning the influence it has on economic growth as well as on other macroeconomic variables.

In the years following 2008 global economic crisis, post-transition EU countries have, almost universally, applied economic policy of active public debt management, 
which, without exception, primarily focused on stabilizing it, and by doing that, automatically accepting the doctrinal theoretical and vague empirical framework of public debt impact on the economy. Regardless of varying attitudes towards the issues of public debt, in the post-crisis environment it became a number one policy issue and one of fundamental determinants of official IMF and EU policies, as well as of national macro-policies expressed through austerity and fiscal consolidation policies.

Such deficit-focused policies can have more or less pronounced implications on management's investment decisions as well as on households saving and spending propensity. Effects of such policies on corporations and households depend on how fiscal adjustments are achieved - through tax increase, public investment cuts, current spending cuts or though combination.

Nevertheless, such government debt policies can have contractionary or expansionary effect which largely depends on certain policy's ability to crowed in or crowd out private sector investments. A fundamental reason why, to some extent, certain policies will impact the private sector lies in its ability to encourage consumption and investing, though alleviating expectations and sparking optimism.

This research was motivated by the assumption that post-crisis attitude towards public debt might not only be justified as public debt growth nor by the fact that it has to be a result of expansive fiscal policies, institutionalized social mechanisms or irresponsible governments but, rather, a result of the applied economic growth model and insufficient monetary and fiscal coordination.

By researching the public debt macroeconomic determinants, this paper attempts to confirm the hypothesis that for reducing the public debt-to-GDP ratio the most important thing is to positively influence the GDP growth factor, the denominator, rather than directly target reduction of public debt levels through fiscal adjustments, the numerator. This view promotes the idea that public debt is a macroeconomic cause rather than a consequence, emphasizing its endogenous character.

Without the intention of minimizing the negative consequences public debt can have on economy, this paper argues that public debt in post-transition NMS countries was not the main cause of post-crisis anemic growth, but that the main cause can be found in unprecedented economic growth rates which were impossible to achieve and which, in turn, increased debt levels. This impossibility, it is believed, stems from structural weaknesses of the economies themselves (structure of the economy, structure of government spending, etc.) but also from inadequate institutional architecture and EU-imposed regulation, which in its recommendations on public debt management did not take into account the structural weaknesses and specificities of the NMS countries

The paper follows the standard research paper structure. In the introductory chapter we start with the hypothesis that public debt crisis is not the cause but rather the outcome of institutional and financial failures. It is believed the results would contribute to reshaping the reform paths in these countries. In the second chapter, relevant literature is reviewed through theoretical debate framework, establishing relevance of the debate for the EU post-transition New Member States. Interaction of the theoretically relevant variables and their assumed influence is provided in the third chapter. Public debt determinants are tested and the empirical analysis is carried out in the fourth chapter, while the findings are provided in the last one. 


\section{Journal of Contemporary Management Issues}

\section{LITERATURE OVERVIEW: DETERMINANTS OF PUBLIC DEBT}

For the past few years, within the theoretical discourse, the issue concerning the public debt crisis has intensified. The mainstream, neoclassical economic theory argues the damaging impacts of permanent budget deficits and high public debt on national saving, investment and net export.

On the other side, the heterodox approaches, mainly Post-Keynesian theoreticians, perceive the public debt in accordance with the Keynesian and Minskyian principles, understanding it as an institutional monetary and financial phenomenon, pointing out the institutional weakness of both the EU and the EMU, with regard to the inherent financial instability of the overall construct of the "money manager capitalism".

In case the public debt problem is caused by lack of fiscal responsibility within the formal policy framework, the problem can be addressed by further implementing the supply-side reforms, structural changes and austerity measures within an export-led strategy (German money mercantilism), and, basically, as a forced convergence.

Because of the joint conservative monetary policy and limited fiscal policy, the countries are basically left only with market reforms. The fundamental point for this concept is the conviction that the stateless currency $^{1}$, trough financial integration, coupled with the free flow of capital, in turn, yields greater competitiveness and growth, and thus - an increase in convergence. Financial integration as a driver of growth and convergence seems as a naive notion.
In his extensive critique, De Grauwe (2013) points out that the problem is structural in nature. The fundamental purport of our approach is that public debt crisis is basically a monetary and financial epiphenomenon. The public debt issue is the outcome of structural disturbances produced by the institutionally weak EMU/EU, as well as by the existing discrepancy between monetary and fiscal policy (so called rupture). ${ }^{2}$

All the while, the decentralised fiscal policy is burdened and limited by regulations, making it essentially a deflationary policy, one having the sole goal of preserving the currency value. In contrast to the monetary nonsovereign countries, public debt in principle does not present a problem for the monetary sovereign ones', as long as it can be financed through deficit, without sparking the inflation.

Because of the scope of crisis that has gripped the periphery of EMU, a large portion of literature has been dedicated to these countries. On the other hand, most NMS kept their currencies, making it interesting to explore how much austerity policy has contributed to increasing competitiveness and stabilizing and reducing the public debt.

However, a question remains: is the public debt crisis of the national monetary systems a balance of payments problem (less competitiveness), or a monetary, financial and structural issue?! The Post-Keynesian approach presupposes the latter, where both, growth and convergence of these countries, is under the influence of the capital influx, with the financial market volatility (subject to boom and bust cycles) causing both the volatility of private debt and GDP, as well as the necessary public debt increase. The public debt fluctuations, according to this particular approach, is a necessary regulator

\footnotetext{
The fundamental critique of EMU had been provided by Pargues (1999) at its very beginning.

2 The Euro, as a stateless private currency, is the means of exchange, but not a policy instrument.
} 
of national stability, with the fluctuations of public debt boiling down to the financial sector regulation, as well as the institutional fiscal policy reform, with no regard for alternatives chosen - a banking union, fiscal union or by abandoning a "one-size-fits-all" policy.

In this particular section a research overview with regard to the relation between the chosen variables, proposed by previous researches, and the public debt, with emphasis on NMS is provided. With the onset and passing of the economic crisis, the fiscal policy impact on the economic growth has regained its significance in the scientific and research community. The fiscal policy, along with the other economic policies, has a key impact on both the short and long-term economic activity.

With the onset of the 2008 global economic crisis, numerous countries have, at first with the activation of automatic stabilisers (such as the social expenditures, the unemployment benefits, etc.) tried to alleviate the detrimental crisis' effects, and later with financial stimulation (increase in the government expenditure, tax policy reforms, etc.), thus aiming at encouraging the aggregate demand and consequently, the GDP growth of national economies. Considering the decrease of tax revenues, as a result of the diminished private sector economic activity, such increase in public spending has necessarily led to the budgetary turn, served to once again encourage the discussions on the relationship between public debt and economic growth, more precisely, what is the nature of that relationship (linear or non-linear) (Cecchetti, et al., 2011), and what is, if any, the causal link between them (Panizza and Presbitero, 2013).

The research that followed, including works of Reinhart and Rogoff $(2010)^{3}$, Cecchetti et al. (2011), Minea and Parent (2012), Checherita-Westphal et al. (2012) as well as many others, confirm the nonlinear and complex relationship, while in the same time highly questionable, and ultimately even reverse causality between the two variables (Irons and Bivnes, 2010; Herndon et al., 2013; Dube, 2013).

Channels of influence of public debt on growth are numerous. For example, Cecchetti, et al. (2011) hold that the high indebtedness may significantly increase the risk premium influencing the future financing activities. Kumar and Woo (2010) concluded that the negative influence of high government indebtedness can be linked to the decline in work productivity due to the decline of investment activities, i.e. the accumulation of fixed capital. With regard to the research dealing with Eurozone member states and the NMS, most of the research conducted analyse the (non)linearity relationship between the public debt and economic growth, as well as their impact on the GDP growth rate, with a smaller research portion focusing on the macroeconomic determinants of public debt, concentrating largely on EU member states (Mota et al., 2012; Globan and Matošec, 2016). ${ }^{4}$

\footnotetext{
3 In particular, Reinhart \& Rogoff (2010) have tested and confirmed a thesis regarding the non-linear correlation between the size of public debt and economic growth, concluding that there is a certain threshold of public debt to GDP, after which any further public debt increase negatively affects economic growth.

4 Swamy (2015), based on a sample of multiple countries, concludes that the GDP growth rate, the FDI influx, the government expenditures, as well as inflation, have negative effects on the public debt, with the investments in fixed capital and the countries' trade openness impacting the public debt favourably.
} 
In contrast to the papers examining the public debt impact on the GDP, we tend to agree with the theoretical outlook of Dube (2013) as well as many other authors, who hold that the GDP fluctuations from previous periods influences the present public debt, a causality which, in Granger's viewpoint, has been proved. ${ }^{5}$

Based on the works of Gros (2015) and others, the variables of both external debt and current account, the latter serving as an approximation of capital influx, have been included in the model, while the PostKeynesian theory and Keen (2013) hold that the public debt is not the source of the problem, but that the private debt, the loans, resulted in the inclusion of private debt. This means that, in principle, the public debt default is not the cause of crisis but the default of private debt. Moreover, with the onset of the crisis, the cause of GDP decrease is a sudden drop in capital influx, thus inducing public debt growth. It is supposed that external debt positively influences public debt, taking into account large capital inflows before the crisis.

At the very beginning, the relation between variables are presented in the scatter diagrams (see Appendix) with predicted values. The scatter diagrams contain estimated regression impact line for each of the macroeconomic variables that proved to have statistical significance on the public debt to GDP variable.
The analysis was conducted on a sample of 11 EU NMS post-transition countries ${ }^{6}$ in the period from $1995-2015$.

In line with the assumed impact of GDP growth on declining public debt to GDP ratio, the scatter diagram indicates that the decrease of public debt to GDP ratio is only possible through increase in investment activity. The primary budget deficit did not have significant influence on public debt in NMS countries. The external debt positively influenced public debt taking into account large capital inflows before the crisis. The scatter diagrams show that, within the NMS, a greater development and convergence of national monetary systems, based on capital influx, ultimately causes macroeconomic imbalances. In such a manner, the current account deficit impacts the public debt, while, in the same time, positively influencing GDP. The cause for GDP decrease with the onset of the crisis is the sudden drop in capital influx, thus inducing public debt growth. The decrease in "private insurance channel" has been replaced by the "public insurance channel", signifying the overall increase in public debt. The fear of inflation and the collapse of the common currency trough market segmentation and weakened financial integration has resulted in financial consolidation and austerity measures which have proved to be recessionary.

This practically means that the import (consumption-led) growth strategy, while transitioning to an export-led strategy in

\footnotetext{
5 Pairwise Granger Causality Tests

Sample: 1995 - 2015

Lags: 2
}

\begin{tabular}{lccc}
\hline Null Hypothesis: & Obs & F-Statistic & Prob. \\
\hline DEBT does not Granger Cause GDP_GROWTH & 201 & 0.70394 & 0.4959 \\
GDP_GROWTH does not Granger Cause DEBT & & 4.01285 & 0.0196 \\
\hline
\end{tabular}

6 Bulgaria, Croatia, Czech, Estonia, Hungary, Latvia, Lithuania, Poland, Romania, Slovak Republic and Slovenia. All countries are members of EU 
post-crisis times in these countries with declining current account deficit (due to austerity measures), is achieved at a lower income levels, as was shown by Staehr (2015). The long-term reduction of public debt is possible by accelerating growth, and accordingly, lower post-crisis growth is an obstacle to significantly reducing public debt as the ratio.

\section{VARIABLES AND THE EXPECTED EFFECTS}

Taking into account the findings of previously conducted research, the following section aims at identifying the main macroeconomic variables that have been identified as statistically significantly influencing the dependent variable of public debt to GDP, as well as at laying out their expected influence on the dependent variable. The research is carried out on a sample of 11 post-transitional countries, all of them being EU member states, and almost half being Eurozone members ${ }^{7}$. The period researched includes data from $1995-2015$. The data on variables used in the research include different sources, namely WDI database of World Bank for investments in fixed capital, trade openness and final consumption; WIIW database for total general government debt, price indexes, current account balance, real GDP growth rate as well as the FDI inflow (in \% of GDP), Eurostat database for the 10-year government bonds yields; and finally ECB database for the primary budget balance. Data for consolidated private sector debt (in \% of GDP) were obtained from Eurostat.

The identified macroeconomic variables used as public debt to GDP determinants, for the purpose of this research are as follows: trade openness, expressed as the ratio between the sum total of imports and exports to GDP, the inflation rate, expressed as the yearly change of the harmonized price index $(2005=100)$, the real GDP growth rate (in percentage points), the primary government budget balance (as percentage of GDP), as well as the investment in fixed capital, as the proxy variable for total investments in economy (yearly growth rate), the current account balance (as percentage of GDP), total government expenditures (as percentage of GDP), total consumption (as percentage of GDP), expressed as the sum of government and household final consumption). The last variable represents the measure of aggregate absorption for the entire economy. Along with the already mentioned variables, the 10-year government bonds yield and the total FDI inflow (in \% of GDP) to sampled countries are also used.

Prior to presenting the results of the econometric analysis, the expected influence of the mentioned variables on the dependent variable is explained.

The trade openness is expected to lower the public debt to GDP ratio of a particular country (Berg \& Krueger, 2003).

The inflation rate, a variable that is assumed to reflect the macroeconomic stability, has a negative expected impact on public debt, assuming that a country with low inflation has the option of borrowing under more favourable conditions, while at the same time, the burden of repaying the mentioned debt, under high inflation conditions, is effectively lower.

The primary budgetary balance has an expected negative impact on public debt increase, meaning that the improvement in budget balance (deficit decrease) should result in public debt decrease, and vice versa (Globan and Matošec, 2016).

7 Estonia, Latvia, Lithuania, Slovak Republic and Slovenia 
The investment variable, expressed as the investment in fixed capital, should yield negative influence on the dependent variable, under the assumption that it increases the employment rate and GDP.

The total government expenditure variable is assumed to have a positive impact on the public debt, meaning its increase, with particular respect to its structure, (expenditure in productive endeavours, such as R\&D), should ultimately lead to the decrease of public debt, with vice versa also being true.

With regard to the impact of the longterm government bond yield, the research suggests the existing positive correlation with public debt (Globan and Matošec, 2016), which can be explained with the creditors' insistence on the higher interest rates, with the increase of public debt and, correspond-ingly, the risk premium.

The FDI is supposed to negatively impact the public debt, in a way that it, as a form of "imported" savings, influences the increase of productivity and "know-how", thus decreasing the need for public borrowing (Mota et al., 2012).

According to Keen, causality between public debt and economic growth can only be explained by understanding the process of creation and change in private debt. Keen provides theoretical framework, concluding that private debt change influences employment, whereby the crisis begins when private debt to GDP starts declining, i.e. when private sector starts deleveraging and public debt starts growing as a response to rising unemployment. He also recognizes theoretical limitations of the existing models, thereby rejecting the neutrality of debt, primarily because of its endogenous creation, thus rejecting the thesis of bank neutrality, and banking and financial systems in general, as debt creating systems. Keen acknowledges that the bank loans raise total purchasing power in the economy because banks make profit, thus affecting aggregate demand. By this he is referring to endogenous money theory. With this contribution, Keen also rejects neoclassical and Neo-Keynesian theoretical models, considering them as defective (Keen, 2014).

On the other hand, the importance of private sector is also emphasized by Michel Roberts who goes further, considering that divergence between credit growth and GDP growth is not a good indicator as public debt partially takes over the growth function (Roberts, 2012). For this reason, he sees Marx's law of profitability as a better indicator that gauges the divergence between declining profits and credit growth, thereby replacing GDP with profitability. In this regard, Roberts considers the best profitability indicator to be the net worth, which, according to him, is to be compared against capital (fixed assets but also aggregate assets which include financial (fictitious) capital as well). Roberts establishes that public debt growth coincides with private sector investment in fictitious capital (financial assets) as a result of private sector profitability (net worth) decline. Decline in profitability levels cause a fall in investment level and contraction of the economy, which again causes a rise in private debt. If the private sector needs to be "rescued" by the government, there is also a rise in public debt. The public sector is not directly involved in the causality process, as he sees it. 
4. RESEARCH METHODOLOGY, ECONOMETRIC ANALYSIS RESULTS AND MANAGERIAL IMPLICATIONS

The econometric analysis carried out utilises the panel analysis models, with the random effects model and with the included robust estimate errors, with intention of eliminating the heteroscedasticity issue. Also, with the aim of controlling the residual autocorrelation, a lagged dependent variable of general government debt, expressed as the part of GDP has as well been included as yet another explanatory variable.

Random effects model is a simple linear model, which supposes that the main criteria for unit inclusion corresponds to randomness principles. Also, it presumes that the differences between subjects are based on randomness. A random effects model has the following formulation:

$$
\begin{aligned}
& y_{i t}=\mu+\beta_{1} x_{i t 1}+\beta_{2} x_{i t 2}+\ldots+\beta_{k} x_{i t K}+ \\
& +\alpha_{i}+\varepsilon_{i t} ; i=1, \ldots N, t=1, \ldots, T
\end{aligned}
$$

With $\mu$ as the common, constant for all the sampled units, $\alpha_{i}$ signifying the random effect for each sampled unit. The premise of the model is that $\alpha_{i}$ are independent and identically distributed random variables across all of the sampled units, with the mean value of zero and the variance of $\sigma_{\alpha}^{2}$, while $\beta_{1}, \ldots, \beta_{K}$, are the parameters that need to be assessed. Also, the assumption is that $\varepsilon_{i t}$ are independent and identically distributed random variables across all of the sampled units, with the mean of 0 and the variance of $\sigma_{\varepsilon}^{2}$.

The validity of using a random effects model is carried using the Lagrange multiplier test (LM). If $\alpha_{i}=0$ holds true for each sampled unit $i$, there is no need to use a random effects model. The assumption of the model is that $E\left(\alpha_{i}\right)=0$ and if this particular condition, as well as $\sigma_{\alpha}^{2}=0$ holds true, the randomness effect may be excluded from the model.

If the LM value of the Breusch-Pagan test is less than $\chi_{\alpha}^{2}(1)$, for the given significance level of $\alpha$, the null-hypothesis, the one which assumes that the random effect variance of observable units is equal to zero, isn't rejected. Therefore, it can be concluded that the heterogeneity between the observed units is non-existent, so the use of random effects model is unnecessary.

If the LM value of the Breusch-Pagan test is greater than $\chi_{\alpha}^{2}(1)$ for the given significance level of $\alpha$ the null-hypothesis is rejected, the one assuming the random effect variance equals zero. Therefore, it is concluded that, in case the random effect variance is greater than zero, heterogeneity between observed units exists, so the random effects model is suitable for parameter assessment.

The econometric analysis tests the following equation (the carried LM test rejects the null-hypothesis for all the panel models, accepting the random effects model as the appropriate one for assessing the following parameters):

With the $\mu$ signifying the common, constant for all the sampled units, $\alpha_{i}$ is the random effect for each sampled units, is the general government debt expressed as the percentage point of GDP, in the time period $t$; is the real GDP growth rate, with the vector of other explanatory variables. The following table showcases the econometric analysis findings. 
Journal of Contemporary Management Issues

Table 1: The random effect static panel (robust error estimates) with Government Debt to GDP ratio as dependent variable

\begin{tabular}{|c|c|c|c|}
\hline Dependent variable $\rightarrow$ & Govdebt_gdp & Govdebt_gdp & Govdebt_gdp \\
\hline Constant & $-17.5407(5.684835)^{* * *}$ & $\begin{array}{c}-21.11394 \\
(5.844929)^{* * *}\end{array}$ & $\begin{array}{l}-14.0788 \\
(8.17655)^{*}\end{array}$ \\
\hline Govdebt_gdp_lag1 & $\begin{array}{c}0.8768619 \\
(0.0419447)^{* * *}\end{array}$ & $\begin{array}{c}0.8404479 \\
(0.0455327)^{* * *} \\
\end{array}$ & $\begin{array}{c}0.8774057 \\
(0.0456862)^{* * *}\end{array}$ \\
\hline Gdp_growth & $\begin{array}{c}-0.3901935 \\
(0.1309248)^{* * *}\end{array}$ & 1 & $\begin{array}{c}-0.4527837 \\
(0.1177069)^{* * *}\end{array}$ \\
\hline Investments_annual & $\begin{array}{c}-0.0549111 \\
(0.0168416)^{* * *}\end{array}$ & 1 & 1 \\
\hline Cabalance_gdp & I & $\begin{array}{c}0.2993412 \\
(0.101017)^{* * *} \\
\end{array}$ & $\begin{array}{c}0.1439048 \\
(0.0734588)^{* *} \\
\end{array}$ \\
\hline Gov_expenditures & $\begin{array}{c}0.4842303 \\
(0.0114611)^{* * *}\end{array}$ & $\begin{array}{c}0.6247266 \\
(0.1141514)^{* * *}\end{array}$ & $\begin{array}{c}0.4249408 \\
(0.1172454)^{* * *}\end{array}$ \\
\hline Tradeop_index & $\begin{array}{c}0.0364532 \\
(0.0138813)^{* * *}\end{array}$ & $\begin{array}{c}0.0245478 \\
(0.0160169)\end{array}$ & l \\
\hline Final_consumption & 1 & I & $\begin{array}{l}0.0452096 \\
(0.069381)\end{array}$ \\
\hline Price_index & 1 & / & l \\
\hline Primary_balance & 1 & 1 & 1 \\
\hline Bond_yield & 1 & 1 & 1 \\
\hline Fdi_inflowgdp & 1 & 1 & 1 \\
\hline Privatedebt_gdp & 1 & 1 & 1 \\
\hline $\begin{array}{l}\text { Number of } \\
\text { observations }\end{array}$ & 212 & 212 & 212 \\
\hline Number of countries & 11 & 11 & 11 \\
\hline $\begin{array}{l}* * * * * * \text { statistical } \\
\text { significance at } 10 \%, 5 \% \\
\text { i } 1 \% \text {, respectively. } \\
\text { Standard error values are } \\
\text { in brackets }\end{array}$ & & & \\
\hline
\end{tabular}

The panel analysis models were used for testing the influence of the selected independent variables on the government debt to GDP dependent variable. In accordance with the results expected, the increase in real GDP growth rates negatively influences the shifts in the dependent variable. Furthermore, two distinct models showed a positive, statistically significant influence of the current account balance on the public debt.

The government expenditure variable positively influenced the public debt, as expected. The variable of investment in fixed capital, using two distinct models turned out to be statistically significant, but with negative impact on public debt, which was anticipated.

The variable of total final consumption and price index did not show statistical significance. In accordance with the presumption, the government long-term bonds yields proved to be statistically significant, coupled with a relatively large economic impact, while variable of FDI inflow also turned out to be statistically significant, but with a negative impact on public debt, which was also anticipated. 


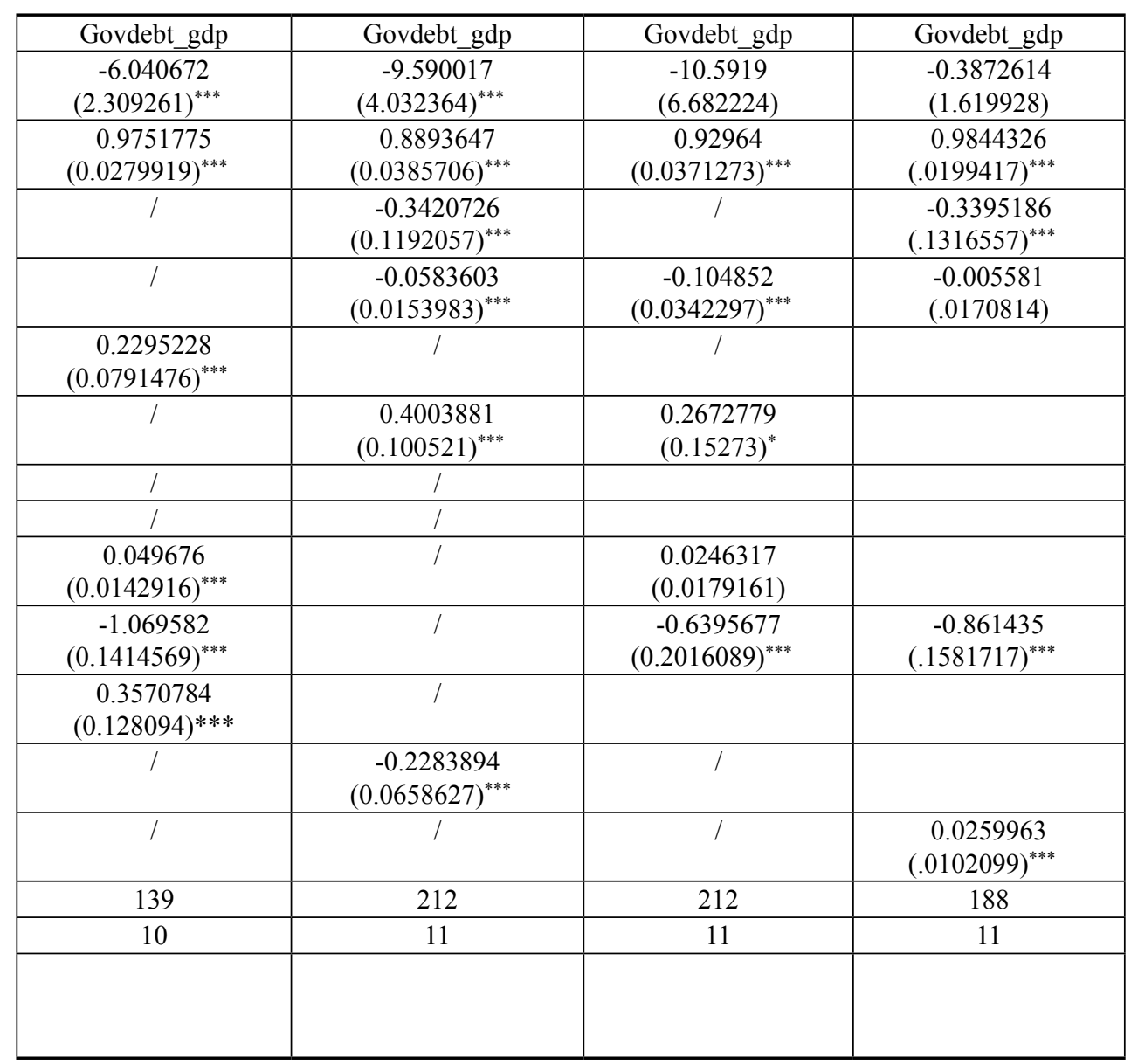

The results from our panel analysis of public debt determinants could be useful for public debt management. Namely, it creates an environment that can impact private sector decisions. This macroeconomic environment contributes to different private sector behaviour, differently influencing households and companies.

As a result of that, successful public debt management will positively influence GDP, lowering long-term public debt to GDP ratio bringing it to sustainable levels. The fiscal consolidation achieved through public spending cuts, which largely characterized public debt policy of the NMS countries, has mainly produced contractionary effect in the short term, negatively influencing the private sector behaviour which largely restrained from increasing consumption and from increasing investments resulting in stagnant GDP. Deflationary character of such policies tended to postpone investments and consumption in the short run because of the falling prices and stagnant wages, limiting private sector indebting despite the extremely low interest rates environment. As such fiscal consolidation limited private sector expectations, directly influencing the private 
sector debt levels, corporation's investments, household spending, and finally, aggregate demand and GDP.

\section{CONCLUSIONS}

Growth of NMS, which are in the focus of our interest, is realized through imbalances, particularly through the current account deficit and the growth of external debt which are both sustainable to the extent of the constant inflow of capital. The instability of "private insurance channel" through sudden stops caused by financial sector frictions and excessive private indebtedness leads to GDP contraction and public debt growth. Thus, the sudden growth of public debt in these countries is primarily a reflection of monetary and financial developments. Within the existing model characterized by the absence of institutional arrangements like fiscal transfers, fiscal union, complete bank union etc., the fear of pubic debt's negative impact on inflation and interest rates, regardless of its size, leads to the necessity of fiscal consolidation and austerity measures that deepen the recession. With the lack of ability to monetize public debt, given the separation between monetary and

\section{REFERENCES}

1. Berg A., Krueger A. (2003): Government Debt and its Macroeconomic Determinants: An Empirical Investigation, IMF Working Paper WP/03/30.

2. Cecchetti, S. G., Mohanty, M. S.,Zampolli, F. (2011): The Real Effects of Debt, BIS Working Papers No. 352. Basel: Bank for International Settlements

3. Checherita-Westphal, C.D., et al, (2012): Fiscal sustainability using fiscal policies (public debt as in the sense of "handbag economics") and with a desire to preserve low and stable prices as the goal of monetary policy, fiscal consolidation and forced convergence are implemented. The fall in the imbalance of payments, and a decrease in the current account deficit and external debt, result in lower growth, weaker impact of public debt cuts, as well as in the slowdown of the convergence process itself. If we accept the conceptual Post-Keynesian stance that public debt is a structural monetary and financial problem, not just the fiscal one, we can say that public debt management and public debt problem solving lies within the necessary institutional changes in the EMU / EU. In other words, in the ability to reconceptualize the monetary and fiscal sphere and in strengthening domestic savings as opposed to volatile capital inflows.

The above results confirm the hypothesis that influencing GDP growth rate is the most important factor for stabilizing and reducing the public debt in the NMS countries. Active and direct public debt management through fiscal consolidation and savings policies can, particularly in the short term, adversely affect GDP and, thus, increase public debt, causing quite the opposite effect from the one desired.

growth-maksimising debt targets, European Central Bank Working Papers, no 1472.

4. Checherita-Westphal, C.D., Rother P. (2010): The impact of high and growing government debt on economic growth. An empirical investigation for the euro area, European Central Bank Working Papers, no 1237.

5. De Grauwe, P. (2013): Design Failures in the Eurozone: Can they be fixed?, LSE Europe in Question, Discussion paper series. 
6. Dube, A. (2013): Guest Post: Reinhart/ Rogoff and Growth in a Time Before Debt, Next New Deal: The Blog of the Roosevelt Institute, http://www.nextnewdeal.net/arindrajit-dube (accessed $22^{\text {nd }}$ May 2013)

7. Globan, T., Matošec, M. (2016): Public Debt-to-GDP Ratio in New EU Member States: Cut the Numerator or Increase the Denominator?, Romanian Journal for Economic Forecasting, 19(3), 57-72.

8. Gros. D., (2015): The Eurozone crisis as a sudden stop: It is the foreign debt which matters, VOX CEPR's Policy Portal, http://voxeu.org/article/ eurozone-crisis-and-foreign-debt (accessed 15. September 2017)

9. Herndon, T., Ash, M., Pollin R. (2013): Does High Public Debt Consistently Stifle Economic Growth? A Critique of Reinhart and Rogoff, Working paper Series, No. 322, Political Economy Research Institute, University of Massachusetts Amherst.

10. Irons, J., Bivens, J. (2010): Government Debt and Economic Growth Overreaching Claims of Debt "Threshold" Suffer from Theoretical and Empirical Flaws, Briefing Paper No. 271, Economic Policy Institute, Washington.

11. Keen, S. (2013). What debt matters most - private or public? https:// www.youtube.com/watch? $\mathrm{v}=5 \mathrm{OLn} 2 \mathrm{sG5Tj0} \quad$ (accessed 26. November 2014).

12. Keen, S. (2014). Time for a Copernican revolution in economics, Business Spectator, http://www.businessspectator.com.au/article/2014/8/25/globalnews/time-copernican-revolution-economics (accessed 5. November 2014).
13. Kumar, M. S., Woo, J. (2010): Public Debt and Growth, IMF Working Paper 10/174, Washington, D.C.

14. Mencinger, J., Aristovnik, A., Verbič, M. (2015): Revisiting the role of public debt in economic growth: The case of OECD countries, MPRA Paper No. 67704.

15. Minea, A., Parent, A. (2012): Is high public debt always harmful to economic growth? Reinhart and Rogoff and some complex nonlinearities, Working Paper 8, Association Francaise de Cliometrie.

16. Mota, P. R., Costa Fernandes, A. L., Nicolescu, A. C. (2012): The Recent Dynamics of Public Debt in the European Union: A Matter of Fundamentals or the Result of a Failed Monetary Experiment?, Faculdade de Economia do Porto, Working Paper, issue 467.

17. Panizza, U., Presbitero, A.F., (2013): Public Debt and Economic Growth in Advanced Economies: A Survey, MoFiR Working paper No. 78.

18. Parguez, A.: (1999): A monetary theory of public finance, International Journal of Political Economy, vol. 32, no. 3, pp. 80. -97.

19. Reinhart, C. M., Rogoff, K. S. (2010): Growth in a Time of Debt, American Economic Review, 100(2), 573-578.

20. Sinha, P., Arora, V., Bansal V. (2011): Determinants of Public Debt for mid-dle income and high income group countries using Panel Data regression, MPRA Paper No. 32079.

21. Swamy, V. (2015): Government Debt and its Macroeconomic Determinants An Empirical Investigation, MPRA Paper No. 64106.

22. Verbeek, M. (2008): A Guide To Modern Econometrics, 4. edition. London: John Wiley \& Sons. 


\section{Journal of Contemporary Management Issues}

\section{APPENDIX}

Figure 1: Relationship between Government Debt to GDP ratio and GDP growth rate

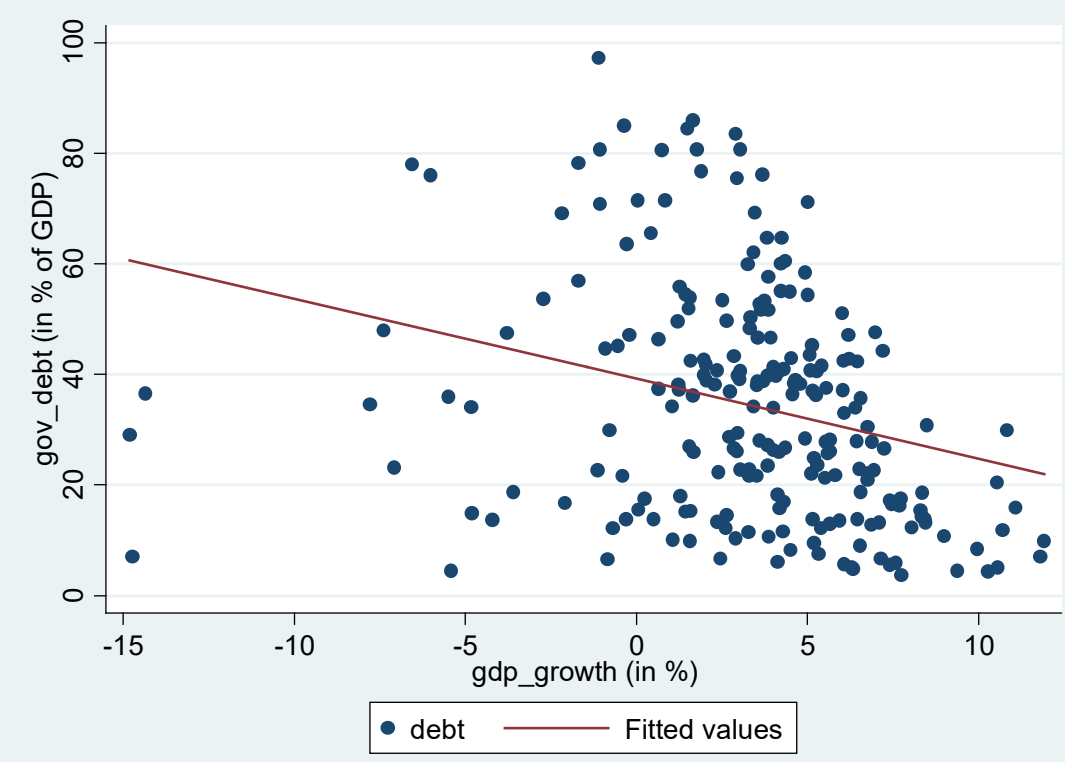

Figure 2: Relationship between Government Debt to GDP ratio and General Government Expenditures to GDP ratio

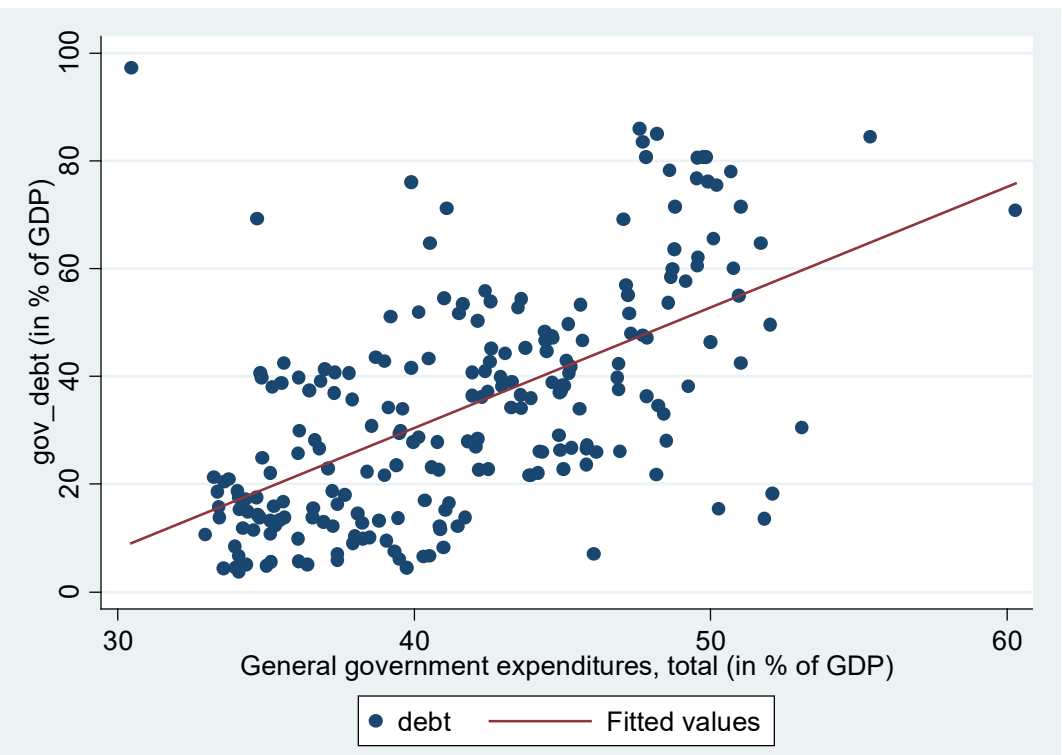


Figure 3: Relationship between Government Debt to GDP ratio and Investments Growth rate

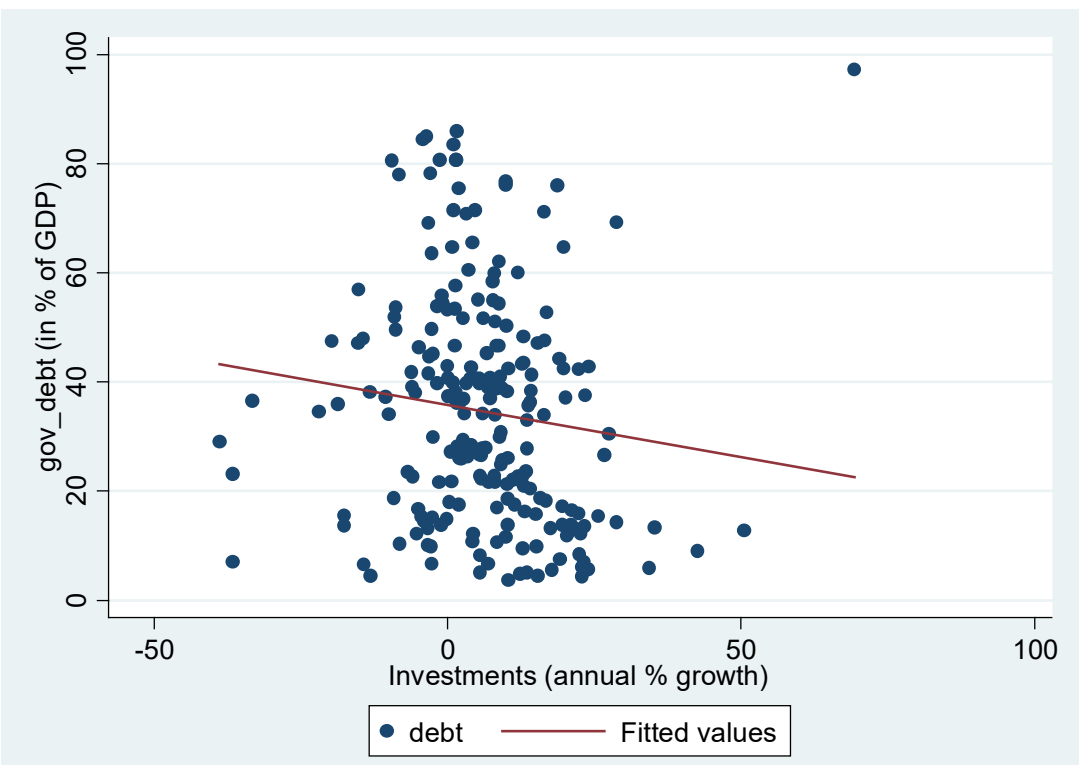

Figure 4: Relationship between Government Debt to GDP ratio and Primary Budget Balance to GDP ratio

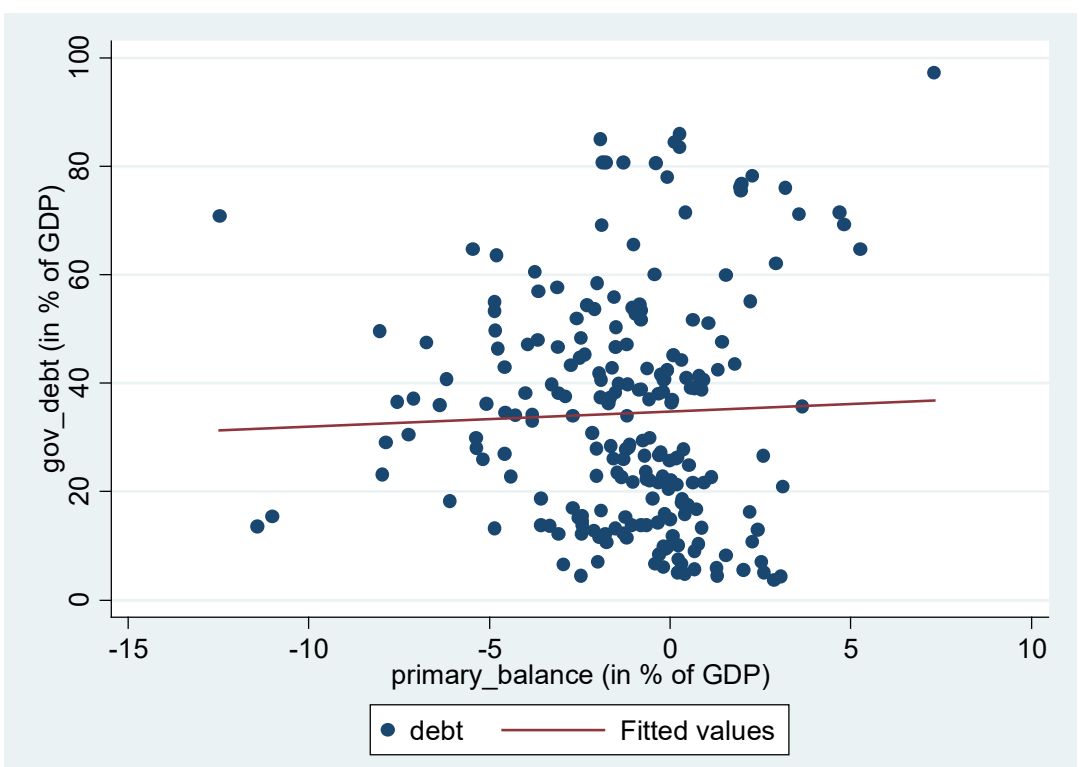




\section{Journal of Contemporary Management Issues}

Figure 5: Relationship between Government Debt to GDP ratio and Real Average Interest Rate Paid on Governemnt Bonds

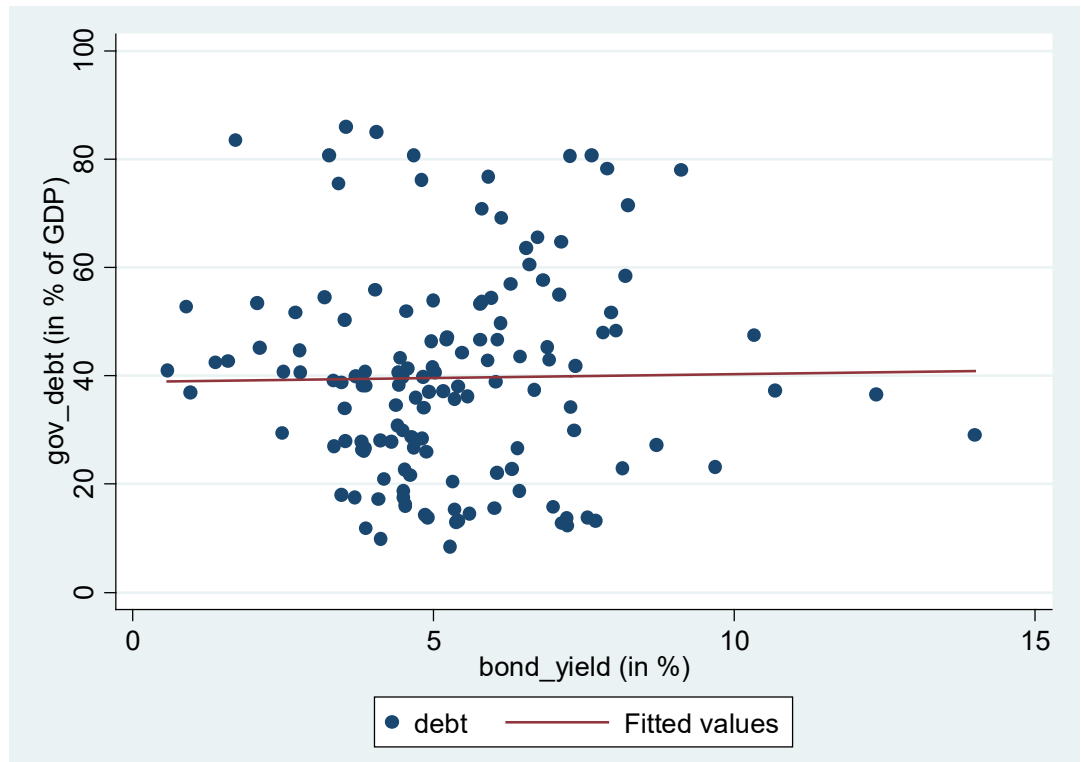

Figure 6: Relationship between Government Debt to GDP ratio and Current Account Balance to GDP ratio

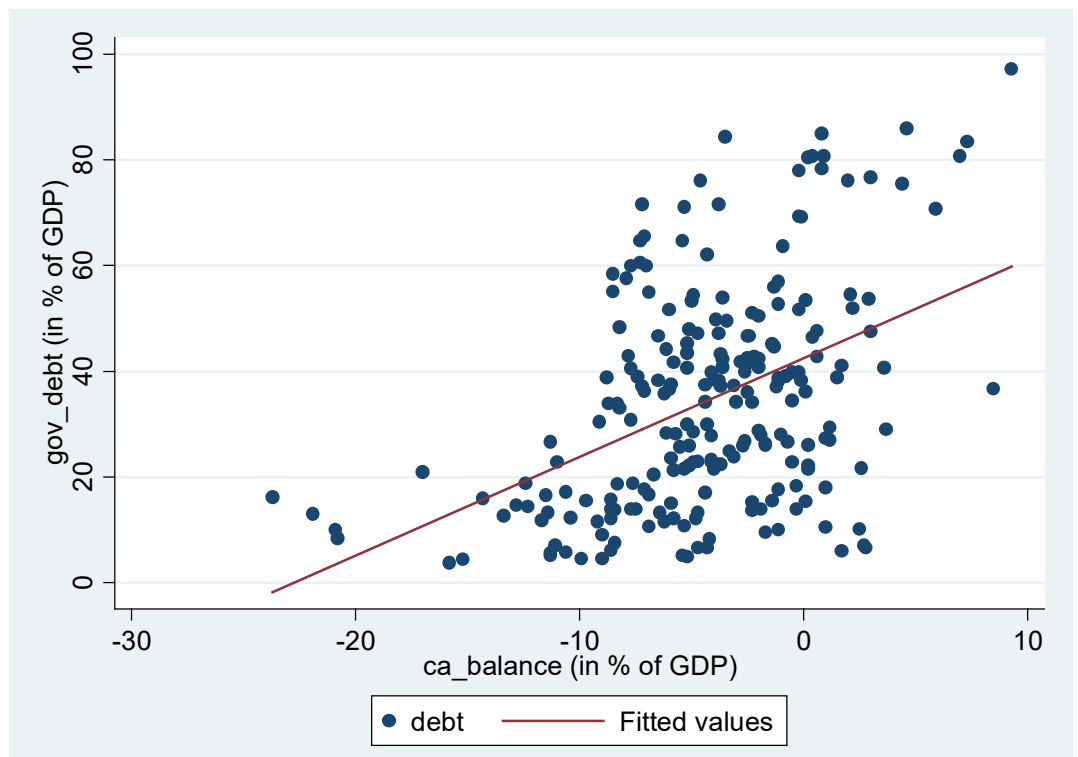


Management, Vol. 23, 2018, No.1, pp. 81-97 M. Pečarić, V. Slišković, T. Kusanović: PUBLIC DEBT IN NEW EU MEMBER STATES - PANEL...

Figure 7: Relationship between Government Debt to GDP ratio and FDI inflow

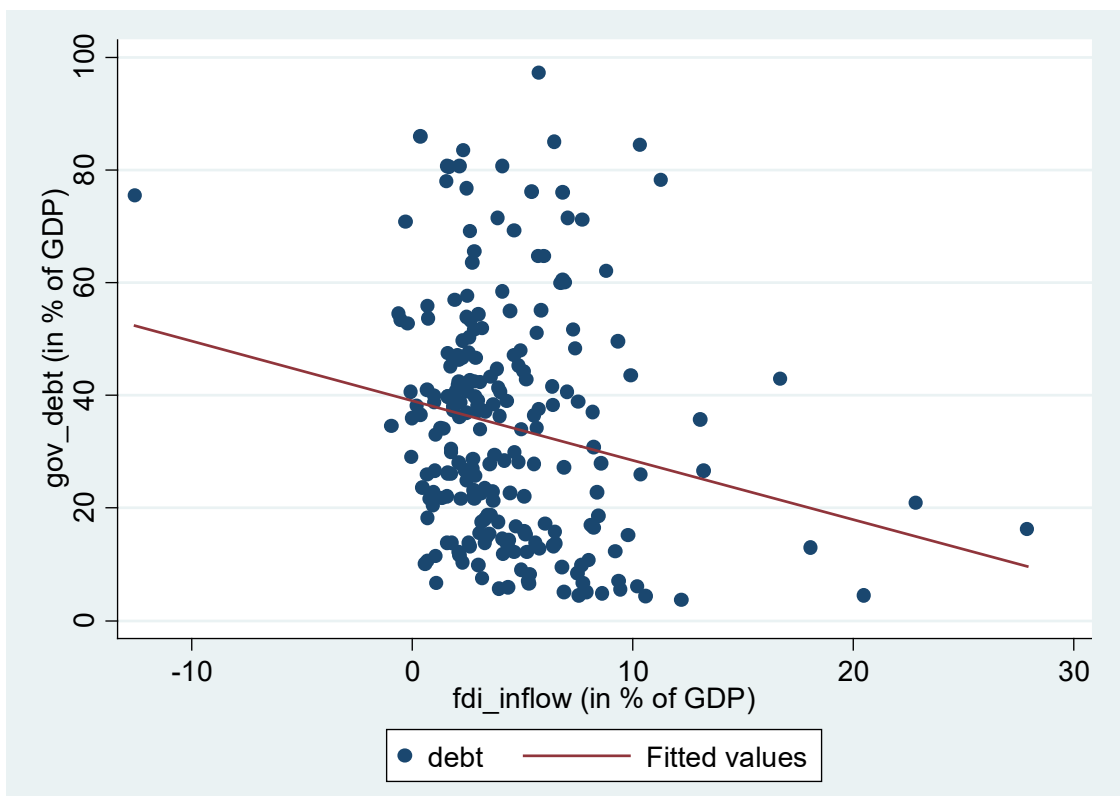


